Reprod. Nutr. Dévelop., 1981, 21 (6B), 1049-1058.

\title{
Reduction of body weight during growing and holding periods and subsequent semen production and fertility in turkeys
}

by F. L. CHERMS, M. G. STOLLER *, J. J. MacILRAITH, K. C. AFRICA, H. R. HALLORAN **

Nicholas Turkey Breeding Farms, Ine.

19449 Riverside Drive, Sonoma, California 95476.

* 726 West Heintz Street, Molalla, Oregon 97038.

** Halloran Research Farm, Inc.

524 Roscoe Road, Modesto, California 95351.

\section{Introduction.}

As breeders of large white turkeys have made genetic improvement in body size and conformation, problems in managing breeding males have become accentuated. The main problem is one of obtaining semen from large, broad toms. There are some reports in the literature in which studies have been conducted to determine the effect of reduction in body size of males on subsequent semen production. Voitle ef al. (1972) found that feeding turkey males a growing feed lower in protein than normally used definitely had an effect on body weight. In this instance, however, there was no difference in fertility between the restricted and non restricted males. The use of lysine restriction has been tested by Muller, 1973, and he found that this caused a delay in sexual maturity of from 5-7 weeks. Krueger et al. (1977) reported that males maintained on a daily feed restriction of 50 p. 100 of feed consumed by full-fed males had a 30 p. 100 reduction in body weight at 30 weeks of age. Restricted males maintained on $15 \mathrm{hrs}$ of light as well as full-fed males maintained on either 8 or 12 hrs of light produced increasing volumes of semen from 32-62 weeks of age. Full-fed males on a 15-hrs day were reported to show a decline in semen production. Hens inseminated with semen from restricted males had higher fertility than either of the other groups in this study.

The present study consists of four experiments conducted in four separate years examining various procedures of reducing body weight in turkey males as well as studying some interactions with lighting regimes.

\section{Procedure.}

Experiment 1 (R030065). - A total of 260 males hatched June 14, of the Nicholas Large White Male Line (Line 50) were brooded for this experiment. The design of the experiment is shown in table 1. Dietary content and calculated composition for feeds used in this, and all subsequent experiments, are given in table 3. At 2 weeks of age half the 
TABLE 1

Experimental design for experiment R030065

\begin{tabular}{cccc}
\hline Group & 2 to 20 weeks & 21 to 32 weeks & Abbrev. \\
\hline 1 & Full feed & Full feed & F-F \\
2 & Full feed & 80 p. 100 Restriction & F-R \\
3 & 80 p. 100 Restriction & Full feed & R-F \\
4 & 80 p. 100 Restriction & 80 p. 100 Restriction & R-R \\
\hline
\end{tabular}

birds were kept on full feed while the other half went on the restricted regime. At 20 weeks of age the number of toms was reduced by selection for physical characteristics to 96 toms (24 per treatment). At 25 weeks of age additional selection by physical characteristics was made and the number reduced to 48 toms (12 per treatment). The criteria for selection is described in the Breeder Management Manual of Nicholas Turkey Breeding Farms, Inc. (1978). The toms were mated to hens that had been maintained on a similar feeding regime. Eggs were set biweekly, and candled at 7 days of incubation and fertility was defermined over a 20-week production cycle. At each insemination semen volumes were obtained on individual males. All toms were weighed at various ages throughout the period from 2-55 weeks of age.

Experiment 2 (R030057). - Toms used in this experiment were of a two-way cross Large White Nicholas experimental male line. A total of 200 tom poults hatched June 24, were started in the brooder house. The experimental design for this experiment is shown in table 2 . At 18 weeks of age the number of toms was reduced to 67 . At

TABLE 2

Experimental design for experiment R030057

\begin{tabular}{cll}
\hline Age & Control & Low protein \\
\hline $1-2$ & Starter 1 & Starter 1 \\
$3-5$ & Starter 2 & Starter 3 \\
$6-9$ & Starter 3 & Grower 1 \\
$10-13$ & Grower 1 & Grower 2 \\
$14-17$ & Grower 2 & Low lysine holding \\
18 & Grower 3 & Low lysine holding \\
$19-27$ & Holding & Holding \\
$28-58$ & Breeder & Breeder \\
\hline
\end{tabular}

25 weeks of age a further reduction of tom numbers was made reducing the number to 48 toms or 24 per experimental group. Hens to which the toms were mated were maintained on feeding regimes similar to the toms. Fertility was obtained through an 18-week production period and eggs were set at biweekly intervals. Semen volumes were obtained on a per tom basis at each insemination. Body weight measurements were made at each change of feed during the growing period and at various stages during the holding and breeding period.

Experiment 3 (R030058). - A total of 825 Nicholas Large White Male Line toms (Line 50) were started in the brooder house on June 30. At two weeks of age the birds were randomized into three groups and started on the experimental regime shown in 
TABLE 3

Composition of diets and calculated nutrient content.

\begin{tabular}{|c|c|c|c|c|c|c|c|c|c|c|c|c|c|c|}
\hline \multirow{3}{*}{ Ingredient } & \multicolumn{14}{|c|}{ Diet (p. 100) } \\
\hline & \multicolumn{3}{|c|}{ Storter } & \multicolumn{3}{|c|}{ Grower } & \multicolumn{2}{|c|}{$\begin{array}{l}\text { Expt'1 } \\
\text { Starter }\end{array}$} & \multicolumn{3}{|c|}{$\begin{array}{l}\text { Expt'1 } \\
\text { Grower }\end{array}$} & \multirow{2}{*}{$\begin{array}{l}\text { Low } \\
\text { Lysine } \\
\text { Holding }\end{array}$} & \multirow{2}{*}{ Holding } & \multirow{2}{*}{$\begin{array}{l}\text { Tom } \\
\text { Breeder }\end{array}$} \\
\hline & 1 & 2 & 3 & 1 & 2 & 3 & $2^{\text {Sta }}$ & $\begin{array}{l}\text { Irter } \\
3\end{array}$ & 1 & & 3 & & & \\
\hline (n) & 23.12 & 31.46 & 41.59 & - & - & - & 44.85 & 54.75 & - & - & - & 94.43 & - & 29.35 \\
\hline Milo ............. & 10.00 & 9.99 & 9.99 & 61.56 & 67.55 & 71.43 & 9.99 & 10.00 & 68.54 & 71.92 & 76.85 & - & 65.75 & 35.22 \\
\hline Soybean Meal, $47 \%$... & 54.24 & 47.69 & 40.34 & 29.72 & 19.98 & 16.98 & 26.49 & 17.63 & 15.23 & 10.86 & 5.87 & 1.12 & 2.38 & 0.75 \\
\hline Safflower Meal, $20 \%$.. & - & - & - & 2.62 & 7.12 & 6.49 & 8.62 & 7.13 & 10.11 & 11.86 & 12.25 & - & 27.87 & 27.98 \\
\hline Safflower Meal, $\mathbf{4 2} \%$.. & - & - & - & - & - & - & - & 3.25 & - & - & - & - & - & - \\
\hline Alfalfa, $18 \% \ldots \ldots \ldots$ & 1.00 & - & - & - & - & - & - & - & - & - & - & - & - & - \\
\hline Limestone ............. & 0.75 & 0.62 & 0.62 & 0.75 & 0.62 & 0.87 & 0.63 & 0.50 & 0.75 & 0.62 & 0.75 & 0.75 & 0.63 & 0.62 \\
\hline Defl. Phosphate. & 2.92 & 2.80 & 2.65 & 2.42 & 2.32 & 2.10 & 2.92 & 2.75 & 2.50 & 2.37 & 2.15 & 1.95 & 1.90 & 1.84 \\
\hline Fat $\ldots \ldots \ldots \ldots \ldots \ldots$ & 2.37 & 1.87 & 1.75 & 0.50 & 0.50 & 0.50 & 1.00 & 1.00 & 0.50 & 0.50 & 0.50 & - & - & - \\
\hline$\ldots \ldots \ldots \ldots \ldots$ & 0.25 & 0.25 & 0.28 & 0.30 & 0.30 & 0.30 & 0.25 & 0.28 & 0.30 & 0.30 & 0.30 & 0.25 & 0.20 & 0.20 \\
\hline DL-Methionine ....... & 0.15 & 0.18 & 0.14 & 0.14 & 0.11 & 0.08 & 0.11 & 0.08 & 0.07 & 0.07 & 0.09 & - & 0.03 & 0.01 \\
\hline Whey $\ldots \ldots \ldots \ldots \ldots$ & - & - & - & - & - & - & - & - & - & - & - & - & - & - \\
\hline Nufac .............. & 2.50 & 2.50 & - & - & - & - & 2.50 & - & - & - & - & - & - & 1.25 \\
\hline Amprol $25 \% \ldots \ldots \ldots$ & - & 0.05 & 0.05 & - & - & - & 0.05 & 0.05 & - & - & - & - & - & - \\
\hline Baciferm $40 \ldots \ldots \ldots$ & - & 0.05 & 0.05 & - & - & - & 0.05 & 0.05 & - & - & - & - & - & - \\
\hline Selenium Premix...... & 0.05 & 0.05 & 0.05 & - & - & - & 0.05 & 0.05 & - & - & - & - & - & - \\
\hline \multirow[t]{2}{*}{ Vit/Min. Premix...... } & 2.50 & 2.50 & 2.50 & 2.00 & 1.50 & 1.25 & 2.50 & 2.50 & 2.00 & 1.50 & 1.25 & 1.50 & 1.25 & 2.50 \\
\hline & $*$ & 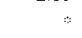 & $\because$ & , & $* *$ & $*$ & $\because$ & $\because$ & & w: & $* *$ & $* *$ & *** & $* * n$ \\
\hline \multicolumn{15}{|c|}{ Calculated Composition } \\
\hline \multicolumn{2}{|c|}{ Energy $(\mathrm{kcal} / \mathrm{kg}) \ldots \ldots 2748$} & 2814 & 2904 & 2875 & 2897 & 2939 & 2816 & 2904 & 2875 & 2897 & 2939 & 3234 & 2695 & 2695 \\
\hline$\%$ Crude Protein ...... & 30.50 & 29.74 & 24.50 & 20.89 & 17.43 & 16.15 & $\quad 20.71$ & 17.60 & 16.10 & $0 \quad 14.42$ & 12.52 & 9.14 & 12.95 & 12.84 \\
\hline$\%$ Lysine............. & 1.79 & 1.60 & 1.37 & 1.07 & 0.80 & 0.71 & 1.05 & 0.81 & 0.70 & 0.57 & 0.43 & 0.28 & 0.39 & 0.39 \\
\hline \% Methionine........ & 0.54 & 0.54 & 0.46 & 0.40 & 0.34 & 0.30 & 0.40 & 0.34 & 0.29 & 0.27 & 0.26 & 0.21 & 0.23 & 0.22 \\
\hline \% Meth. and Cystine... & 1.05 & 1.01 & 0.88 & 0.75 & 0.63 & 0.57 & 0.76 & 0.66 & 0.56 & 0.51 & 0.48 & 0.38 & 0.45 & 0.46 \\
\hline$\%$ Crude Fat . .......... & 4.33 & 4.07 & 4.07 & 2.41 & 2.48 & 2.54 & 3.58 & 3.70 & 2.49 & 2.53 & 2.60 & 3.78 & 1.88 & 2.40 \\
\hline$\%$ Crude Fiber ........ & 3.49 & 3.25 & 2.95 & 3.88 & 5.39 & 5.12 & 6.12 & 5.68 & 6.41 & 6.99 & 7.07 & 2.55 & 12.58 & 12.72 \\
\hline$\%$ Calcium........... & 1.37 & 1.25 & 1.18 & 1.14 & 1.06 & 1.08 & 1.27 & 1.16 & 1.16 & 1.07 & 1.04 & 0.94 & 0.94 & 0.92 \\
\hline \% Phosphorus-avail... & 0.71 & 0.68 & 0.63 & 0.58 & 0.54 & 0.49 & 0.68 & 0.63 & 0.57 & 0.54 & 0.49 & 0.43 & 0.46 & 0.46 \\
\hline \% Phosphorus-total... & 1.01 & 0.96 & 0.90 & 0.83 & 0.78 & 0.73 & 0.94 & 0.90 & 0.81 & 0.78 & 0.72 & 0.62 & 0.72 & 0.72 \\
\hline
\end{tabular}

Vitomin/Mineral premix contained not less than the amount given per kilogram of supplement for each feed.

* Vitamin A, 90, $910 \mathrm{IU}$; Vitamin $\mathrm{D}_{3}, 31,820 \mathrm{ICU}$; Vitamin E, $110 \mathrm{lU}$; Vitamin K, $27 \mathrm{mg}$; Riboflavin, $55 \mathrm{mg}$; Niacin, $545 \mathrm{mg}$; d-Pantothenic Acid, $145 \mathrm{mg}$; Choline, $5455 \mathrm{mg}$; Thiamine, $9 \mathrm{mg}$; Pyridoxine, $27 \mathrm{mg}$; Vitomin B $12,90 \mathrm{mcg}$; d-Biotin, $0.9 \mathrm{mg} ;$ Folic Acid, $9 \mathrm{mg} ;$ Selenium, $1.65 \mathrm{mg}$; Manganese, $33 \mathrm{mg}$; lodine, $0.6 \mathrm{mg}$, Cobalt, $0.2 \mathrm{mg}$; Iron, $20 \mathrm{mg}$; Copper, $2.2 \mathrm{mg}$; and Zinc, $29 \mathrm{mg}$.

**Vitamin A, 127, $270 \mathrm{IU}$; Vitamin $D_{3}, 45,450 \mathrm{lCU}$; Vitamin E, $145 \mathrm{lU}$; Vitamin K, $36 \mathrm{mg}$; Riboflavin, $91 \mathrm{mg}$; Niocin, $727 \mathrm{mg}$; d-Pontothenic Acid, $182 \mathrm{mg}$ : Choline, $7,270 \mathrm{mg}$; Thiamine, $18 \mathrm{mg}$; Pyridoxine, $36 \mathrm{mg}$; Vitamin $B_{12}, 127 \mathrm{mcg} ; \mathrm{d}-$ Biotin, $0.45 \mathrm{mg} ;$ Folic Acid, $14 \mathrm{mg}$; Selenium, $3.3 \mathrm{mg}$; Manganese, $65 \mathrm{mg}$; lodine, $1.1 \mathrm{mg}$; Cobalt, $0.4 \mathrm{mg}$; Iron, $40 \mathrm{mg}$; Copper, $4.4 \mathrm{mg}$; and Zinc, $57 \mathrm{mg}$.

** Vitamin A, 81, 820IU; Vitamin D, 31, $820 \mathrm{ICU}$; Vitamin E, $318 \mathrm{lU}$; Vitamin K, $36 \mathrm{mg}$; Riboflavin, $64 \mathrm{mg}$; Niacin, $455 \mathrm{mg}$; d-Paniothenic Acid, $155 \mathrm{mg}$; Choline, $3636 \mathrm{mg}$; Thiamine, $18 \mathrm{mg}$; Pyridoxine, $32 \mathrm{mg}$; Vitamin $B_{12}, 109 \mathrm{mcg} ; \mathrm{d}-$ Biotin, $0.9 \mathrm{mg}$; Folic Acid, $11 \mathrm{mg}$; Selenium, $1.50 \mathrm{mg}$; Manganese, $33 \mathrm{mg}$; lodine. $0.6 \mathrm{mg}$; Cobalt, $0.2 \mathrm{mg}$; Iron, $20 \mathrm{mg}$; Copper $2.2 \mathrm{mg}$; and Zinc, $29 \mathrm{mg}$.

table 4. The low protein program was started at 3 weeks of age and continued to 17 weeks. At that point this group of males went on the regular holding feed. The birds in the restricted group were maintained on a regular program until 18 weeks of age. From 18-30 weeks of age they were maintained on a program of skip the weekend feeding. This regime was designed to study body weight reductions at two different periods in the bird's life. At 20 weeks of age the number of toms per treatment group was reduced to 28 . A further reduction of tom numbers occurred at 24 weeks of age at 
TABLE 4

Experimental design for experiment R030058

\begin{tabular}{clll}
\hline Week & Control & Low protein & \multicolumn{1}{c}{ Restricted } \\
\hline $1-2$ & Starter 1 & Starter 1 & Starter 1 \\
$3-5$ & Starter 2 & Exptl. st. 2 & Starter 2 \\
$6-9$ & Starter 3 & Exptl. st. 3 & Starter 3 \\
$10-13$ & Grower 1 & Exptl. gr. 1 & Grower 1 \\
$14-17$ & Grower 2 & Exptl. gr. 2 & Grower 2 \\
$18-30$ & Holding & Holding & Holding-skip week end \\
31 & Tom breeder & Tom breeder & Tom breeder \\
\hline
\end{tabular}

which time there were 21 toms per experimental group. Data on body weight, semen production and fertility were obtained as in the previous experiments.

Experiment 4 (R030059). - The 210 poults of a Nicholas Large White Male Line (Line 50) utilized in this study were hatched on June 28. The experimental design used in this experiment was similar to that used in Experiment 3 with two exceptions. In the low protein group from the period of 18-21 weeks of age an additional feed was included in the regime (table 5). Also in the restricted group the toms were placed on a

TABLE 5

Experimental design for experiment R030059

\begin{tabular}{clll}
\hline Age & Control & Low protein & \multicolumn{1}{c}{ Restricted } \\
\hline $1-2$ & Starter 1 & Starter 1 & Starter 1 \\
$3-5$ & Starter 2 & Exptl. st. 2 & Starter 2 \\
$6-9$ & Starter 3 & Exptl. st. 3 & Starter 3 \\
$10-13$ & Grower 1 & Exptl. gr. 1 & Grower 1 \\
$14-17$ & Grower 2 & Exptl. gr. 2 & Grower 2 \\
$18-21$ & Grower 3 & Exptl. gr. 3 & Holding-skip week end \\
$22-30$ & Tom breeder & Tom breeder & Tom breeder \\
\hline
\end{tabular}

tom breeder feed at 22 weeks of age and from 18-26 weeks of age the birds were starved for 3 days. As in the other three experiments body weight measurements were obtained at the point at which a feed was changed up to 22 weeks of age. From this point to 30 weeks of age biweekly measurements were obtained. During the breeding season body weights were obtained at four different intervals. Semen production data and fertility information were obtained as in the other experiments.

\section{Results and discussion.}

Experiment 1 (R030065). - Body weight data from 2-55 weeks of age are shown in figure 1 . The greatest reduction in body weight was obtained by the $R-R$ group. At 31 weeks of age this group was 89.6 p. 100 of the weight of the control. This reduction in body weight is not as great as that reported by Voitle (1972), Muller (1973) or Krueger ef al. (1977).

All toms in this experiment and in experiments 3 and 4 were maintained on a 
FIG. 1. - Body weight curves from 2 to 55 weeks of age for males in four treatment groups in experiment $R 030065$.

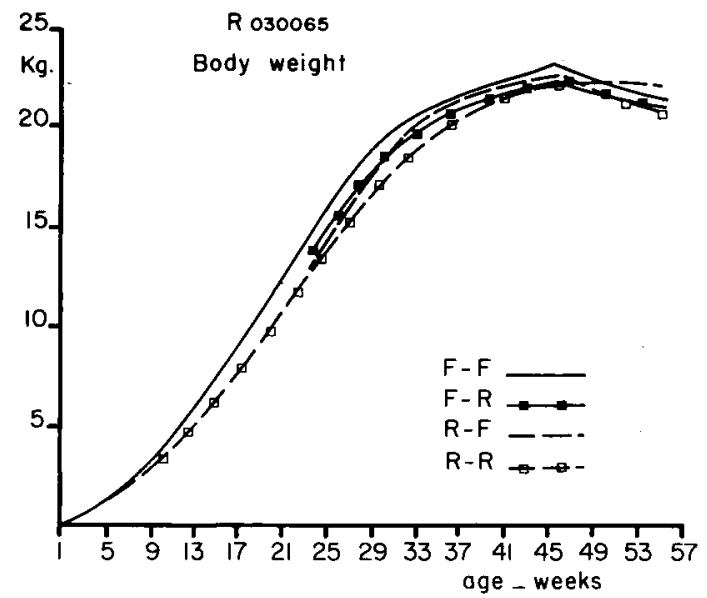

lighting regime which consisted of exposure to a natural day up to 22 weeks of age and from that point to a 12-hour day with a light intensity of 0.5 f.c. This program did not change for the remainder of the reproductive life. The semen production curves for each of the four experimental groups as well as the average semen volume per tom per ejaculate and the percent fertility are shown in figure 2 . The group that had the severest

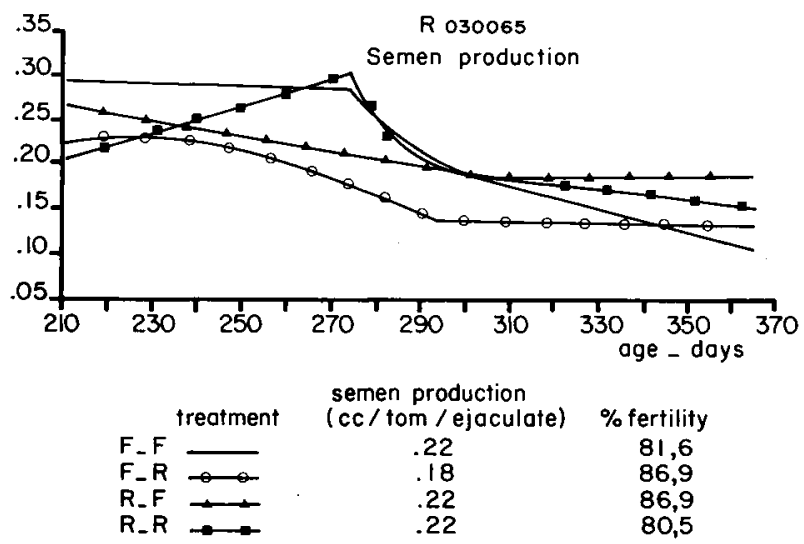

FIG. 2. - Semen production curve, average semen volume per tom per ejaculafe and percent fertility for the four treatment groups in experiment R030065.

weight restriction, namely $R-R$, was delayed in reaching its maximum semen volume by about 9 weeks. The groups R-F and F-R came into semen production somewhat above R-R but below F-F. Groups R-F and F-R exhibited a gradual decline in semen production until about 300 days of age, at which point both groups leveled off in semen production. The full-fed birds (F-F) came in with the highest level of semen production. They maintained this level until about 275 days of age, and then went throught a steady decline. The average semen volumes per tom per ejaculate were very similar. Fertility 
was numerically higher in the F-R and R-F groups, but not significantly so. The main difference in this experiment was that the control birds came in with higher levels of semen production, but did not hold this level of production near the end of the breeding season. At 365 days they were the lowest semen producers. The lack of difference in semen volumes agrees with the report of Krueger et al. (1977) who likewise did not find a difference in average semen volume per ejaculate when comparing restricted and full-fed males.

Experiment 2 (R030057). - The use of a low protein feesing regime during the early growing period reduced body weight at 32 weeks of age to the point that the low

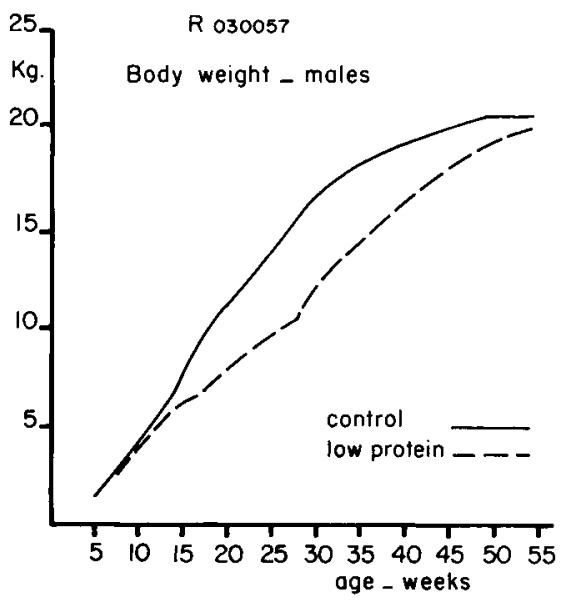

FIG. 3. - Body weight curves from 5 to 54 weeks of age for toms fed a control feed regime and for those fed a reduced protein regime during the growing period (R030057).

protein group was 75.7 p. 100 of the weight of the control (fig. 3). At the termination of the experiment at 54 weeks of age the two groups were very similar in body weight. The delay in reaching peak semen production in the restricted birds in Experi-

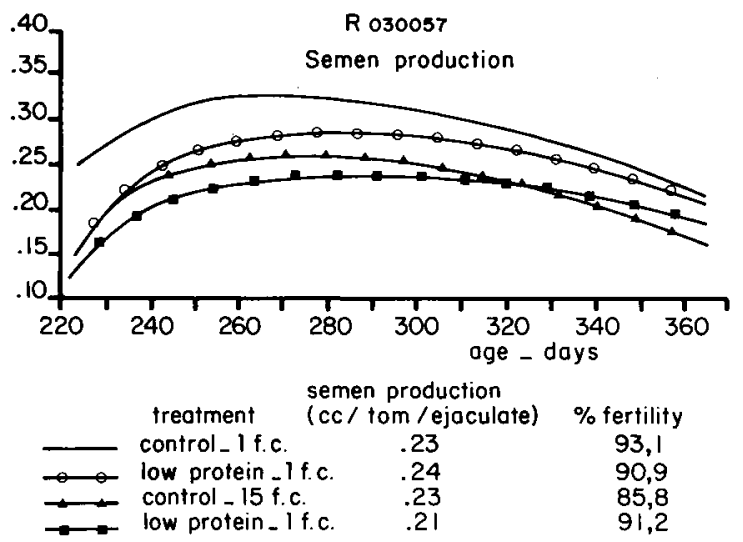

FIG. 4. - Semen production curve, average semen volume per fom per ejaculate and percent fertility for the four treatment groups in experiment R030057. 
ment 1 was thought possibly to be an interaction with the low-light regime followed in the experiment. In Experiment 2 groups of toms from both feed regimes were maintained on either 1 f.c. or 15 f.c. of light beginning at 22 weeks of age. Average semen volume per tom per ejaculate, semen production curves and percent fertility for each group are shown in fig. 4. The birds on the higher light intensity on both feed regimes had lower semen volumes. Likewise the low protein group had lower semen volume than the controls under either light regime. The semen production curve indicates that the low protein group was slower coming into semen production and its peak was lower than the control group under both light regimes. In all groups there was a decline in semen volume near the end of the breeding season. Fertility was not affected by either feed regime or light intensity to which the toms were exposed. The findings in this experiment tend to corroborate those of Experiment 1 where toms maintained on a program to reduce body weight showed a delay in sexual maturity. This adverse effect was not reversed by increased light intensity. However, semen produced by all groups in this experiment was capable of maintaining high levels of fertility.

Experiment 3 (R030058). - The body weight graphs for each treatment group are shown in fig. 5 . At 32 weeks of age the birds fed a low protein diet during their early

FIG. 5. - Body weight curves from 2 to 52 weeks of age for the control, low protein and skip weekend groups of toms in experiment R030058.

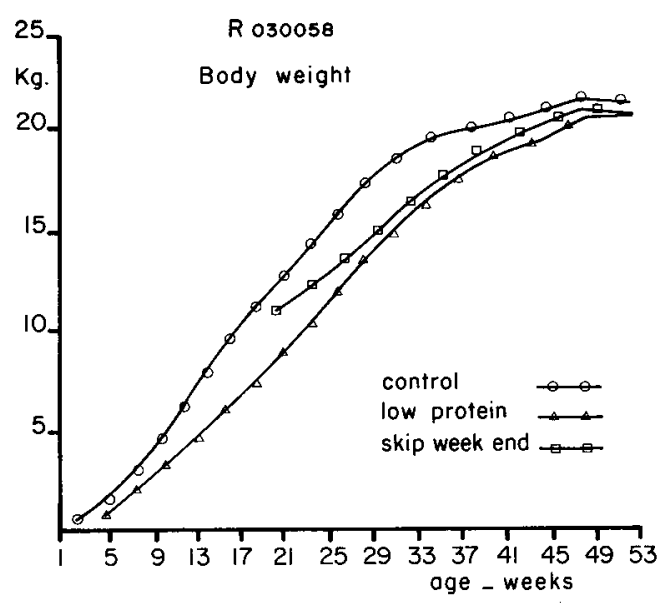

growth period weighed 82.6 p. 100 of the controls. The restricted feed group, in which the program was applied during the holding period, weighed $85.2 \mathrm{p} .100$ of the controls at 32 weeks of age. As in the other experiments all three groups were close in body weight at the termination of the test.

Semen production curves, the average semen volume per tom per ejaculate and fertility are shown in fig. 6. In this experiment the birds on the restricted program had the greatest delay in sexual maturity. In all three groups there tended to be a constant rise in semen production, up to about 320 days of age. At that point both the low protein and the restricted groups tended to show a reduction in production. The control continued an upward trend. There was, however, no significant difference in the 


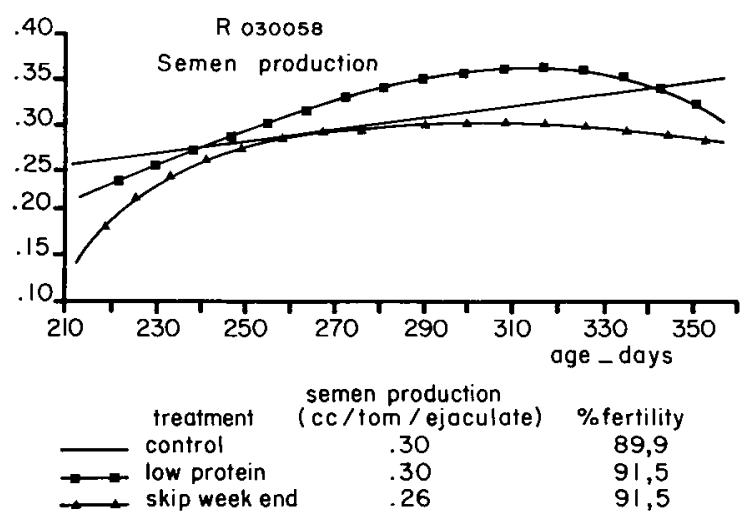

FIG. 6. - Semen production curve, overage semen volume per fom per ejoculate and percent fertility for the three treatment groups in experiment R030058.

average semen volume per tom per ejaculate in any group. Also there was no significant difference in fertility. This experiment agrees with the findings of both Experiments 1 and 2 in that the reduction of body weight in males tends to delay the onset of semen production. The greatest difference appears to be in toms in which body weight reduction is attempted during the holding period. When done during an early age the effect on semen production is not as great. A problem with reducing body weight during the growing period is that it creates difficulties in making phenotypic selections of males at the standard ages of 16 to 18 weeks.

Experiment 4 (R030059). - This experiment was basically a repeat of Experiment 3 with the minor exceptions noted in the procedural section. As occurred in Experiment 3 the greatest reduction in body weight was attained by the low protein regime during

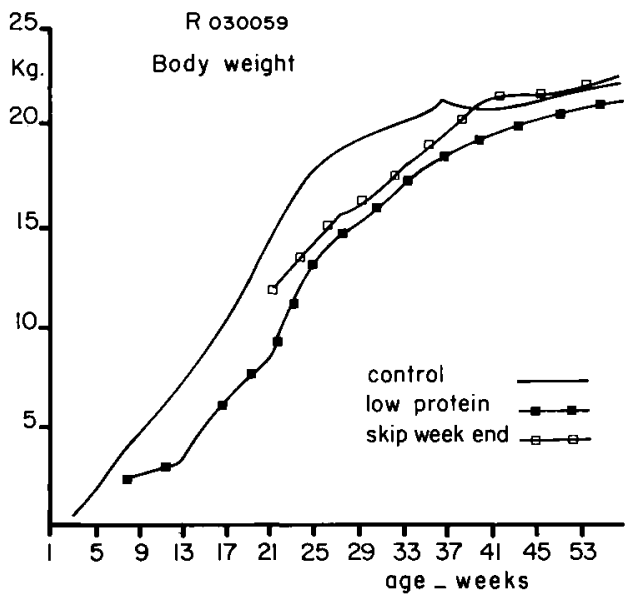

FIG. 7. - Body weight curves from 3 to 52 weeks of age for the control, low protein and skip weekend groups of toms in experiment R030059.

the early growing period (fig. 7). At 30 weeks of age this group weighed 80.1 p. 100 of the controls. At that age the restricted feeding group weighed 81.9 p. 100 of the 
controls. As in the other experiments the body weights were quite similar at the termination of the experiment.

Semen production as measured by average semen volume per ejaculate per tom and fertility for each of the three groups is shown in fig. 8 and indicates as in other

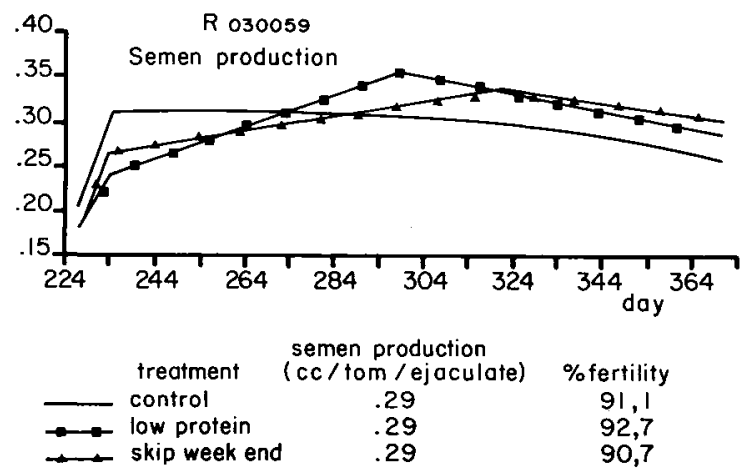

FIG. 8. - Semen production curve, average semen volume per tom per ejaculate and percent fertility for the three treatment groups in experiment R030059.

tests no difference between the treatment groups. There were, however, differences in the onset of semen production. The controls in this instance were slower reaching their peak production than in the other tests, however they were still above the levels attained by the low protein and skip the weekend groups. In both the low protein and skip the weekend groups semen production continued to rise until 304 to 320 days and then began to decline. In the control group the peak production was attained at 244 days with a slight drop and then a constant level from 274 to 374 days of age.

The fact that in all four experiments birds that went through a program to reduce body weight were somewhat slower in attaining their maximum semen production can have important practical complications. Under most commercial insemination programs hens are inseminated three times in the first 10 days of lay. This puts a great deal of pressure on the tom during that early period and any delay in sexual maturity would result in a shortage of semen at that time.

Figure 9 is a summary of semen production in all four experiments where controls were combined and all groups in which body weight reductions were attained were

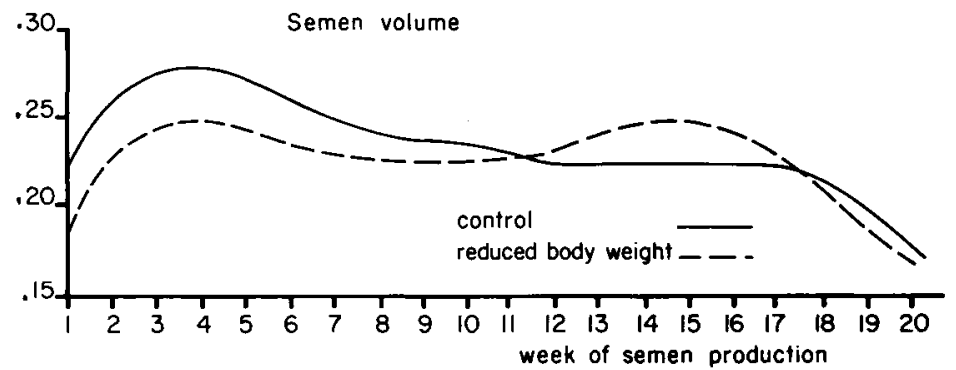

FIG. 9. - Composite semen production curve for toms in four separate experiments maintained on a control feeding program and on programs designed to reduce bojy weight. 
also combined. This shows that reducing body weight does have an effect on early semen volume. It also shows that later on there tends to be higher semen volumes in males that go through a body weight reduction program. From a practical standpoint the higher semen volume later in the season is probably not significant because at that time some culling has taken place in the hen flock and therefore the semen required is not as great. The results of this study tend not to agree with those of Krueger et al. (1977) who did report that the use of feed restriction tended to result in superior reproductive performance. Unfortunately, in that work there was no indication of whether or not semen production was delayed in restricted toms during the early semen production period.

\section{Conclusions.}

The use of both lower than normal protein during the growing period (2-18 weeks) and of feed restriction during the holding period (18-30 weeks) reduced body weight in Nicholas Large White Male Line toms. Semen production was altered in that early in the production period the birds with reduced body weight were lower than controls, but later in the breeding season the reverse occurred. At the end of the season in each of the four experiments, there was no difference in average semen volume per tom per ejaculate. Fertility was not affected by reducing body weight.

Workshop on «Avian male reproduction 》 Nouzilly, France, June 1980.

Résumé. Dans la souche de dindons Nicholas Large White, l'utilisation de régimes alimentaires restreints en taux protéique de 2 à 18 semaines d'âge, puis en quantité totale distribuée de 18 à 30 semaines d'âge, conduit à une diminution de la croissance corporelle. La production de sperme est, elle aussi, diminuée pendant son début, mais se trouve augmentée plus tard. Il n'apparaît pas d'effet sur la fécondance du sperme.

\section{References}

KRUEGER K. K., OWENS J. A., KRUEGER C. E., FERGUSON T. M., 1977. Effect of feed or light restriction during the growing and breeding cycles on the reproductive performance of Broad Breasted White turkey males. Poultry Sci., 56, 1566-1574.

MULLER H. D., 1973. The effects of severe lysine restriction on body weight and reproductive performance of breeder tom turkeys. Poultry Sci., 52, 2067.

NICHOLAS TURKEY BREEDING FARMS, Inc., 1949. Riverside Drive, Sonoma, California 95476. Breeder Manogement Manual, 1978.

VOITLE R. A., WALTER J. H., WILSON H. R., HARMS R. H., 1972. The effect of low protein grower diet on the reproductive performance of turkey breeder toms. Poultry Sci., 51, 1548-1552. 